appointing a committee of three people chosen from member states not seeking to build the accelerator on their own territory-Denmark, the Netherlands and Switzerland-to narrow down the choice to three sites. The council itself, between September and December next year, will then make a final decision, no doubt in a process in which the three shortlisted countries will find themselves expressing their willingness to accommodate the accelerator by the size of their financial contribution.

The council is also hoping that by the end of 1967 European governments will finally commit themselves to the financing of the accelerator although, on this, hopes may be disappointed. Everything will depend on the extent to which the principal contributors, such as the United Kingdom, feel themselves able to commit substantial sums to the operation of the large accelerator. On the legal side, however, there is more optimism, and there is apparently general opinion among the governments of member states that the $300 \mathrm{GeV}$ laboratory should be governed by the same convention as that which applies to the present laboratory at Geneva. The council has also approved a suggestion that there should be some kind of collaboration between CERN and the Russian laboratory at Serpukhov, where a new $70 \mathrm{GeV}$ accelerator is due to operate in 1967. For a time at least the Russian machine will be the most powerful proton accelerator in the world, although the laboratory at Geneva hopes to have its intersecting storage rings in operation before the new machine in the United States comes into service.

\section{Origin of Genetic Code}

THE genetic code is probably universal, said Dr. F. H. S. Crick, speaking at the winter meeting of the British Biophysical Society on December 20. Although some doubts remained, further evidence would probably show this to be the case. But why should it be universal? There were two possible explanations, he said. One was that it was the only possible code for stereochemical reasons, because the amino-acids fit uniquely either to the codons or to the anti-codons. (The first possibility was suggested by Pelc and Welton earlier this year in Nature, 209, 869; 1966; but Dr. Crick found it quite unacceptable; the second was more likely, and evidence for it seemed to be accumulating.) Another type of explanation for the constancy of the code was that it had become so complicated that any change would be lethal - that the genetic code had got into a rut. The fact that there is only one version of the code and not several co-existing versions still needed to be explained.

Dr. Crick's subject was the origin of the code, and he went on to discuss possible primitive systems. It was clear, for instance, that a primitive system would not need all 20 amino-acids; a system of 4 or 6 aminoacids would be sufficient. The primitive system was likely to be concerned with nucleic acid replication, but the sequence of the nucleic acids had to be right; this would probably have come about by chance. $\mathrm{He}$ said it would be necessary to postulate an enzyme to catalyse the stringing together of the monomers, unless someone could find a mineral with holes of the right size to catalyse the reaction.

According to Dr. Crick, the evolution of the code is unlikely to have taken place by the addition of amino- acids to a primitive system in which a small number of amino-acids was sufficient. But how else?

It was a pity, Dr. Crick said, that there is no other system with which to compare our own. He was pessimistic about finding a system on Mars, but the study of meteorites and fossils might help.

\section{Middle-sized Aid}

A scheme for helping to foster the wider use of simple machinery in underdeveloped countries has been started in London by a group known as the Intermediate Technology Development Group, with Mr. E. F. Schumacher, Economic Adviser to the National Coal Board, as one of the prime movers. He has long been known for his view that advanced nations may be mistaken in seeking to force the pace of development elsewhere by concentrating on aid with sophisticated technical developments. The group, which was set up last February, is being financed by a grant from the Scott-Bader Foundation and by subscriptions from individuals and companies. As its first task, the group has set out to compile a catalogue of items of equipment costing less than $£ 100$ and already being manufactured in Britain-winches, pumps, simple agricultural equipment and the like. The organizers are hoping that the cost of the venture will be at lcast in part offset by charges levied on manufacturers.

On future developments, Mr. A. G. R. Gater, who has left the National Economic Development Council to work with the group, says that the setting up of an information centre to give detailed advice about equipment, to manufacturers as well as to purchasers, would be a natural development of the buyers' guide. Eventually the group may be able to undertake con. sultancy for customers in developing countries. Mr. Gater said that the group had been enormously encouraged by letters of support from individuals and by offers of practical help from people with knowledge of developing countries, many of whom had returned to Britain with the intention of manufacturing equipment intended for use elsewhere. There was a "good head of steam", as he put it.

\section{Hot New Gospeller}

As fast as the 'New Christianity' abandons its position of moral arbitration, technology takes it up. This at least seems to be the feeling of the British Minister of Technology, Mr. Wedgwood Benn, who last week gave the world seven new deadly sins. He was speaking at a luncheon attended by the Directors of the Research Associations, and for all his eloquence, he made the new sins sound far less fun than the old. Briefly, Mr. Benn's sins are Academic Escapism, Graduate Rejection, Student Brainwashing, Industrial Amateurism, Status Hunting, Neo-luddism and Antitechnological Bias.

Some of these, of course, need to be explained, which shows how copywriting has declined since the old list was compiled. Gluttony and sloth used to speak for themselves, and were particularly appropriate for lunchtime occasions, but the new technology somehow lacks the impact of the Old Testament. Mr. Benn did elaborate, of course. "Student Brainwashing" applies to "teachers who try to pick out their so-called "brightest' pupils for so-called 'academic' education, and simultaneously discourage them from seeking careers 